DOI: $10.5216 /$ cab.v12i1.8092

\title{
ECHOCARDIOGRAPHIC ASSESSMENT AFTER INTRAVENOUS AMITRAZ OR XYLAZINE INJECTION IN CATS
}

\author{
Andre Escobar, ${ }^{1}$ Gláucia Bueno Pereira Neto, ${ }^{2}$ Paulo Aléscio Canola, ${ }^{3}$ Marina Ceccato Mendes, ${ }^{4}$ \\ Aparecido Antônio Camacho ${ }^{5}$ e Carlos Augusto Araújo Valadẽo ${ }^{6}$ \\ 1. Faculdade de Ciências Agrárias e Veterinárias da Unesp de Jaboticabal. E-mail: aescobarvet@yahoo.com.br \\ 2. Faculdade de Ciências Agrárias e Veterinárias da Unesp de Jaboticabal \\ 3. Faculdade de Ciências Agrárias e Veterinárias da Unesp de Jaboticabal \\ 4. Faculdade de Ciências Agrárias e Veterinárias da Unesp de Jaboticabal \\ 5. Faculdade de Ciências Agrárias e Veterinárias da Unesp de Jaboticabal \\ 6. Faculdade de Ciências Agrárias e Veterinárias da Unesp de Jaboticabal.
}

\section{ABSTRACT}

Amitraz acts on $\mathrm{a}_{2}$-adrenergic receptors in a competitive and reversible way, leading to some xylazine-like effects. To evaluate the left ventricular function index after amitraz or xylazine administration, eight mongrel cats were submitted to intravenous injection: group X (xylazine), group A (amitraz) or group D (diluent). The same cats were used in all groups, after a 15-day interval. Heart rate (HR) and rhythm, shortening fraction (\%SF), ejection fraction $(\% \mathrm{EF})$ and cardiac index $(\mathrm{CI})$ were measured by echocardiography immediately before and during 60 minutes after drug injection. Amitraz and xylazine induced first-degree atrioventricular block ( $\left.1^{\text {st }} \mathrm{AVB}\right)$ and decreases in $\mathrm{HR}, \% \mathrm{SF}$, $\% \mathrm{EF}$ and $\mathrm{CI}$. The mean values of HR and all echocardiographic parameters of group $\mathrm{X}$ were significantly lower comparing to group A. It was concluded that both $\mathrm{a}_{2}$-agonists produce bradycardia and $1^{\text {st }} \mathrm{AVB}$, but xylazine causes greater depression of the cardiac contractility.

KEYWORDS: Amitraz, xylazine, echocardiography, electrocardiography, cats.

\section{RESUMO}

\section{AVALIAÇÃO ECOCARDIOGRÁFICA DE GATOS APÓS A ADMINISTRAÇÃO INTRAVENOSA DE AMITRAZ OU XILAZINA}

O amitraz age de forma competitiva e reversível em receptores adrenérgicos do tipo $\mathrm{a}_{2}$, desencadeando efeitos similares aos da xilazina. Com o objetivo de avaliar a função ventricular esquerda após a administração de amitraz ou xilazina, oito gatos SRD foram submetidos a injeções intravenosas: grupo X (xilazina), grupo A (amitraz) ou grupo D (diluente). Os mesmos animais foram utilizados em todos os grupos após um intervalo mínimo de quinze dias. Foram avaliados frequência cardíaca (FC), ritmo cardíaco, fração de ejeção (FE), fração de encurtamento (FS) e índice cardíaco (IC), por meio de eletrocardiografia e ecocardiografia, imediatamente antes e durante os primeiros sessenta minutos após a aplicação. Tanto o amitraz quanto a xilazina induziram bloqueio atrioventricular de primeiro grau $\left(1^{\circ} \mathrm{BAV}\right)$ e diminuição de FC, FE, FS e IC. As médias da FC e de todos os parâmetros ecocardiográficos do grupo $\mathrm{X}$ foram estatisticamente menores do que as do grupo A. Concluiu-se que ambos os agonistas adrenérgicos de receptores tipo $\mathrm{a}_{2}$ causaram bradicardia e $1^{\circ} \mathrm{BAV}$; contudo, a xilazina produziu maior depressão na contratilidade cardíaca.

PALAVRAS-CHAVES: Amitraz, xilazina, ecocardiografia, eletrocardiografia, gatos. 


\section{INTRODUCTION}

The $\mathrm{a}_{2}$-agonists have been widely used in veterinary medicine since the 1960's, after xylazine synthesis in Germany, due to their dose-dependent effects on sedation, miorelaxation and analgesia (ALLEN et. al., 1986; GROSS, 2003). Their mechanisms of action are related to the activation of presynaptic $\mathrm{a}_{2}$-adrenoreceptors leading to an inhibitory effect on noradrenaline release and by stimulation of different G proteins (MUIR \& MASON, 1996; VITAL, 2002).

Previous studies have shown that the stimulation of central and peripheral $\mathrm{a}_{2}$-adrenoreceptors agonists affect cardiovascular and myocardial function in small animals (MUIR \& PIPER, 1977; GOLDEN et al., 1998; PADDLEFORD \& HARVEY, 1999). The main cardiovascular effects of all $\mathrm{a}_{2}$-agonists include bradycardia and associated bradyarrhythmias $\left(1^{\text {st }}\right.$ and $2^{\text {nd }}$ degree atrioventricular heart block), reduction in cardiac output (CO), and an initial increase in systemic vascular resistance (SVR) (SINCLAIR, 2003).

Amitraz is an insecticide used in veterinary medicine as an acaricide and tickicide (SHARMA \& DABAS, 1993), whose mechanism of action are similar to other $\mathrm{a}_{2}$-adrenoreceptors agonists (HSU \& KAKUK, 1984; QUEIROZ-NETO et al., 2000; FARIAS et al., 2005). Sedation, analgesia and cardiovascular depression similar to the $\mathrm{a}_{2}-$ adrenoreceptors agonists have been described in several species after amitraz intravenous injection (QUEIROZ-NETO et al., 2000; ALMEIDA et al., 2004; FARIAS et al., 2005; MENDES et al., 2007; LINARDI et al., 2008).

In cats, the intravenous administration of $1 \mathrm{mg} /$ $\mathrm{kg}$ of a $1.5 \%$ amitraz commercial solution induced sedation, bradycardia, first degree atrioventricular heart block ( $\left.1^{\text {st }} \mathrm{AVB}\right)$ and hypotension (ANDRADE et al., 2007). In addition, both yohimbine $(0.1 \mathrm{mg} / \mathrm{kg})$ and atipamezole $(0.2 \mathrm{mg} / \mathrm{kg})$ were effective in the treatment of amitraz injection symptoms, although atipamezole, which has a higher selectivity to $\mathrm{a}_{2}$-adrenoreceptors, was more effective in reversing arrhythmias and sedation (Andrade et al., 2006).

Considering the risks and costs to determine the cardiac function by invasive techniques in cats, echocardiography has been used as the only non-invasive method to accurately verify cardiac dimensions and function indexes on basis of directly measured values (PIPERS and HAMLIN, 1980; DUNKLE et al., 1986). However, there are few echocardiographic reports in cats and none of them describes the effects of amitraz injection. Thus, the aim of this study was to evaluate the heart rhythm and cardiac function after intravenous amitraz or xylazine injection in cats.

\section{MATERIAL AND METHODS}

This study was approved by the Animal Care Committee at São Paulo State University (protocol number 007133-07). Eight healthy mongrel cats weighting $4.1 \pm 1.1 \mathrm{~kg}$ were selected after physical, hematological, thoracic radiographic, electrocardiographic and echocardiographic evaluations. Only cats which had no contact with amitraz during the six months prior the study were used.

After hair clipping between the right $3^{\text {rd }}$ and $6^{\text {th }}$ intercostal spaces, each cat was electrocardiographically and echocardiographically evaluated before (T0 - baseline under physical restraint) and at 5 (T5), 10 (T10), 15 (T15), 20 (T20), 30 (T30), 40 (T40), 50 (T50) and 60 (T60) minutes after treatments. A $24 \mathrm{G}$ intravenous catheter was inserted in the cephalic vein for drug administration. After measurement of baseline data, an intravenous injection of $1.0 \mathrm{mg} / \mathrm{kg}$ of xylazine (group X), or 1.0 $\mathrm{mg} / \mathrm{kg}$ of amitraz diluted in a lipid solution (group A) (FARIAS et al., 2005), or the same volume of the lipid solution used for the previous treatment (group D) was performed in each cat. The order in which each treatment was given was randomly assigned and at least 15 days were allowed between the treatments of each cat.

Electrocardiographic leads were attached to the body of the animals to capture a standard lead II tracing in order to obtain the heart rate (HR) and possible arrhythmias. Simultaneously, M-mode echocardiographic measurements were made with a Pandion S300 echocardiograph (PieMedical, Maastricht, The Netherlands), using a 5- or $7.5-\mathrm{MHz}$ transducer directed towards the heart within the $4^{\text {th }}$ or 
$5^{\text {th }}$ intercostal space. The cats were positioned in right lateral recumbency, on a table specifically designed for veterinary echocardiography, for imaging of the right paraesternal short-axis view at chordae tendineae level from below through an aperture. All echocardiographic measurements used for analysis represent a resultant mean of at least three cardiac cycles.

To evaluate the echocardiographic left ventricular function, the following parameters were measured: left ventricular diameter at end-diastole (LVDd) and at endsystole (LVDs) in cm, interventricular septal thickness at end-diastole (IVSd) and at end-systole (IVSs) in $\mathrm{cm}$, left ventricular free wall thickness at end-diastole (LVWd) and at end-systole (LVWs) in $\mathrm{cm}$, shortening fractional $(\% \mathrm{SF})$, ejection fractional $(\% \mathrm{EF})$ and cardiac index (CI) in $\mathrm{L} / \mathrm{m}^{2} \mathrm{x}$ min, determined by the use of several echocardiographic indexes shown below.

End-systolic left ventricular volume index (ESLVVI) was calculated as $\left(\left(7 \times \operatorname{LVDs}^{3}\right) /(2.4+\right.$ LVDs)) divided by body surface area (BSA) in square meters. End-diastolic left ventricular volume index (EDLVVI) was calculated by the formula $\left(\left(7 \times \mathrm{LVDd}^{3}\right) /\right.$ $(2.4+\mathrm{LVDd})) / \mathrm{BSA}$. M-mode-derived stroke volume (SI) resulted from EDLVVI - ESLVVI, and M-modederived CI was calculated as SI $\times \mathrm{HR}$.

The data were normally distributed and expressed as the mean $\pm \mathrm{SD}$. The variables were compared by one way repeated measures analysis of variance followed by Tukey test. The significance level of all tests was set at $5 \%(\mathrm{P}<0.05)$.

\section{RESULTS}

Compared with mean baseline values, the HR was significantly reduced in all moments during treatment with xylazine (X) and amitraz (A) (Figure 1). Heart rate (HR) was reduced only at 20 minutes $1 n$ the animals treated with the diluent. At 5 minutes, HR reduced $47 \%$ in the group $\mathrm{X}$ and $21 \%$ in the group $\mathrm{A}$; values were reduced during all observation time. The mean HR values of group $\mathrm{X}$ were significantly lower comparing to group A. Although the ECG average values were normal at all times in all experimental groups, one cat (number 2) in group $\mathrm{X}$ at 50 and 60 minutes, and one cat (number 5) in group A at 20, 40, 50 and 60 minutes presented first-degree atrioventricular block $\left(1^{\text {st }} \mathrm{AVB}\right)$, characterized by a PR interval above $90 \mathrm{~ms}$.

The values and significant changes of LVDd, LVDs, SWTd, SWTs, LVTd and LVTs are shown in Table 1 . The $\% \mathrm{SF}$ and $\% \mathrm{EF}$ in group $\mathrm{X}$ were significantly reduced in all moments compared to baseline measurements (59\% and $42 \%$ lower at 5 minutes, respectively) (Figure 2). They were also decreased in group A at 5, 10 and 15 minutes (26\% and $16 \%$ lower at 5 minutes, respectively). However, all echocardiographyc values of group X were significantly lower compared to group A. Data for CI of group X were below baseline values in all moments (68\% lower at 10 minutes) (Figure 1). Cats treated with amitraz had a significant decrease of $\mathrm{CI}$ at 15, 20, 30 and 60 minutes (46\% lower at 30 minutes). After 10 minutes, all CI values of group $\mathrm{X}$ were significantly lower than group $\mathrm{A}$.

TABLE 1. Mean ( \pm SD) echocardiographic values of cats before and after intravenous administration of xylazine (X), amitraz (A) or amitraz diluent (D)

\begin{tabular}{|c|c|c|c|c|c|c|c|c|c|c|}
\hline & & T0 & $\mathrm{T} 5$ & $\mathrm{~T} 10$ & $\mathrm{~T} 15$ & $\mathrm{~T} 20$ & $\mathrm{~T} 30$ & $\mathrm{~T} 40$ & $\mathrm{~T} 50$ & $\mathrm{~T} 60$ \\
\hline LVDd & \multirow{6}{*}{$\mathrm{X}$} & $1.41 \pm 0.2$ & $1.56 \pm 0.3$ & $1.37 \pm 0.3$ & $1.53 \pm 0.3$ & $1.5 \pm 0.2$ & $1.42 \pm 0.2$ & $1.47 \pm 0.2$ & $1.56 \pm 0.1$ & $1.32 \pm 0.2$ \\
\hline LVDs & & $0.65 \pm 0.2$ & $1.27 \pm 0.3$ & $1.0 \pm 0.2$ & $1.1 \pm 0.2$ & $1.1 \pm 0.1$ & $0.98 \pm 0.1$ & $0.93 \pm 0.1$ & $1.01 \pm 0.1$ & $0.85 \pm 0.1$ \\
\hline IVSd & & $0.37 \pm 0.1$ & $0.37 \pm 0.1$ & $0.42 \pm 0.1$ & $0.43 \pm 0.1$ & $0.4 \pm 0.1$ & $0.43 \pm 0.1$ & $0.49 \pm 0.2$ & $0.39 \pm 0.1$ & $0.45 \pm 0.1$ \\
\hline IVSs & & $0.71 \pm 0.1$ & $0.51 \pm 0.1$ & $0.57 \pm 0.1$ & $0.55 \pm 0.1$ & $0.58 \pm 0.1$ & $0.55 \pm 0.1$ & $0.65 \pm 0.1$ & $0.58 \pm 0.1$ & $0.59 \pm 0.1$ \\
\hline LVWd & & $0.46 \pm 0.1$ & $0.35 \pm 0.1$ & $0.41 \pm 0.1$ & $0.37 \pm 0.1$ & $0.38 \pm 0.1$ & $0.38 \pm 0.1$ & $0.44 \pm 0.1$ & $0.41 \pm 0.1$ & $0.42 \pm 0.1$ \\
\hline LVWs & & $0.73 \pm 0.1$ & $0.49 \pm 0.1$ & $0.57 \pm 0.1$ & $0.53 \pm 0.1$ & $0.59 \pm 0.1$ & $0.58 \pm 0.1$ & $0.65 \pm 0.1$ & $0.62 \pm 0.1$ & $0.63 \pm 0$ \\
\hline
\end{tabular}


(... continuação)

\begin{tabular}{|c|c|c|c|c|c|c|c|c|c|c|}
\hline & & T0 & $\mathrm{T} 5$ & $\mathrm{~T} 10$ & $\mathrm{~T} 15$ & $\mathrm{~T} 20$ & $\mathrm{~T} 30$ & $\mathrm{~T} 40$ & $\mathrm{~T} 50$ & T60 \\
\hline LVDd & \multirow{6}{*}{ A } & $1.42 \pm 0.2$ & $1.47 \pm 0.2$ & $1.53 \pm 0.1$ & $1.48 \pm 0.2$ & $1.41 \pm 0.1$ & $1.33 \pm 0.1$ & $1.49 \pm 0.1$ & $1.45 \pm 0.3$ & $1.49 \pm 0.2$ \\
\hline LVDs & & $0.6 \pm 0.2$ & $0.84 \pm 0.1$ & $0.86 \pm 0.1$ & $0.81 \pm 0.1$ & $0.72 \pm 0.2$ & $0.67 \pm 0.1$ & $0.7 \pm 0.1$ & $0.71 \pm 0.2$ & $0.76 \pm 0.2$ \\
\hline IVSd & & $0.38 \pm 0.1$ & $0.39 \pm 0.1$ & $0.41 \pm 0.1$ & $0.39 \pm 0.1$ & $0.41 \pm 0.1$ & $0.41 \pm 0.1$ & $0.41 \pm 0.1$ & $0.41 \pm 0.1$ & $0.43 \pm 0.1$ \\
\hline IVSs & & $0.64 \pm 0.1$ & $0.66 \pm 0.1$ & $0.59 \pm 0.1$ & $0.6 \pm 0.1$ & $0.64 \pm 0.1$ & $0.62 \pm 0.1$ & $0.66 \pm 0.1$ & $0.68 \pm 0.1$ & $0.66 \pm 0.1$ \\
\hline LVWd & & $0.45 \pm 0.2$ & $0.41 \pm 0.1$ & $0.38 \pm 0.1$ & $0.41 \pm 0.1$ & $0.42 \pm 0.1$ & $0.42 \pm 0.1$ & $0.39 \pm 0.1$ & $0.43 \pm 0.1$ & $0.38 \pm 0.1$ \\
\hline LVWs & & $0.74 \pm 0.1$ & $0.58 \pm 0.1$ & $0.58 \pm 0.1$ & $0.6 \pm 0.1$ & $0.63 \pm 0.1$ & $0.65 \pm 0.1$ & $0.69 \pm 0.1$ & $0.64 \pm 0.1$ & $0.66 \pm 0.1$ \\
\hline LVDd & \multirow{6}{*}{$\mathrm{D}$} & $1.32 \pm 0.1$ & $1.39 \pm 0.3$ & $1.32 \pm 0.3$ & $1.32 \pm 0.2$ & $1.2 \pm 0.2$ & $1.27 \pm 0.2$ & $1.32 \pm 0.2$ & $1.29 \pm 0.2$ & $1.26 \pm 0.1$ \\
\hline LVDs & & $0.62 \pm 0.1$ & $0.65 \pm 0.2$ & $0.64 \pm 0.2$ & $0.61 \pm 0.1$ & $0.54 \pm 0.1$ & $0.58 \pm 0.1$ & $0.56 \pm 0.1$ & $0.54 \pm 0.1$ & $0.55 \pm 0.1$ \\
\hline IVSd & & $0.41 \pm 0.1$ & $0.42 \pm 0.1$ & $0.42 \pm 0.1$ & $0.43 \pm 0.1$ & $0.4 \pm 0.1$ & $0.41 \pm 0.1$ & $0.38 \pm 0.1$ & $0.4 \pm 0.1$ & $0.4 \pm 0.1$ \\
\hline IVSs & & $0.66 \pm 0.1$ & $0.64 \pm 0.1$ & $0.64 \pm 0.1$ & $0.69 \pm 0.1$ & $0.67 \pm 0.1$ & $0.68 \pm 0.1$ & $0.65 \pm 0.1$ & $0.66 \pm 0.1$ & $0.65 \pm 0.1$ \\
\hline LVWd & & $0.46 \pm 0.1$ & $0.41 \pm 0.1$ & $0.47 \pm 0.1$ & $0.44 \pm 0.1$ & $0.45 \pm 0.1$ & $0.4 \pm 0.1$ & $0.41 \pm 0.1$ & $0.48 \pm 0.1$ & $0.45 \pm 0.1$ \\
\hline LVWs & & $0.67 \pm 0.1$ & $0.63 \pm 0.1$ & $0.68 \pm 0.1$ & $0.69 \pm 0.1$ & $0.64 \pm 0.1$ & $0.67 \pm 0.1$ & $0.63 \pm 0.1$ & $0.68 \pm 0.1$ & $0.66 \pm 0.1$ \\
\hline
\end{tabular}

\# Bold words $=$ significant difference $(\mathrm{P} \leq 0.05)$ from baseline values; $\mathrm{LVDd}=$ left ventricular diameter at end-diastole $(\mathrm{cm})$; LVDs $=$ left ventricular diameter at end-systole $(\mathrm{cm}) ;$ IVSd = interventricular septal thickness at end-diastole $(\mathrm{cm})$; IVSs = interventricular septal thickness at end-systole $(\mathrm{cm})$; $\mathrm{LVWd}=$ left ventricular free wall thickness at end-diastole $(\mathrm{cm}), \mathrm{LVWs}=$ left ventricular free wall thickness at end-systole $(\mathrm{cm})$.

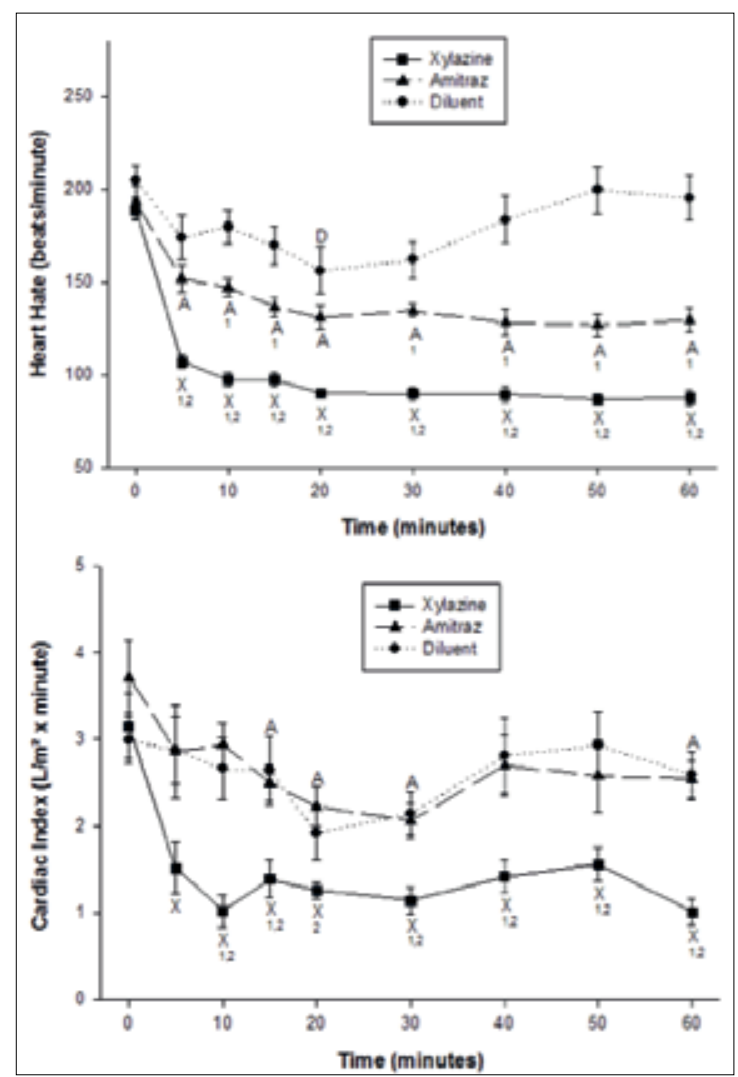

FIGURE 1. Effects of xylazine, amitraz or amitraz diluent intravenous administration on mean $( \pm \mathrm{SD})$ heart rate and cardiac index of cats.

$\mathrm{X}=$ xylazine; $\mathrm{A}=$ amitraz; $\mathrm{D}=$ diluent - significant difference $(\mathrm{P} \leq 0.05)$ from baseline values. $1=$ significant difference $(\mathrm{P} \leq 0.05)$ from group diluents; 2 $=$ significant difference $(\mathrm{P} \leq 0.05)$ from group amitraz.

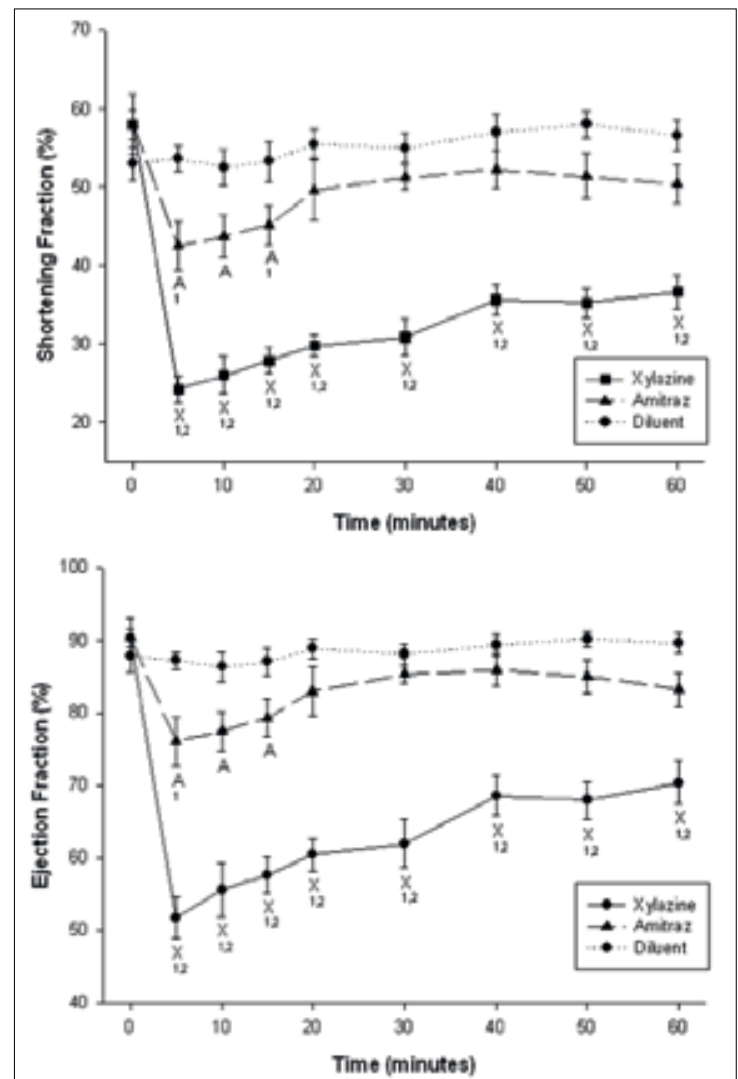

FIGURE 2. Effects of xylazine, amitraz or amitraz diluent intravenous administration on mean $( \pm \mathrm{SD})$ shortening fraction and ejection fraction of cats.

$\mathrm{X}=$ xylazine $; \mathrm{A}=$ amitraz - significant difference $(\mathrm{P} \leq 0.05)$ from baseline values. $1=$ significant difference $(\mathrm{P} \leq 0.05)$ from group diluents; $2=$ significant difference $(\mathrm{P} \leq 0.05)$ from group amitraz. 


\section{DISCUSSION}

The dosage of $1.0 \mathrm{mg} / \mathrm{kg}$ of amitraz used was based on previous reports by ANDRADE et al. (2006) and ANDRADE et al. (2007) that showed the effects caused by intravenous amitraz injection in cats. In one study, sedation, loss of reflexes, mydriasis, bradycardia, bradyarrhythmias and bradypnea were effectively reversed with $0.2 \mathrm{mg} / \mathrm{kg}$ of atipamezole, an $\mathrm{a}_{2}$-adrenergic antagonist with high affinity (ANDRADE et al. 2006). There are few studies with amitraz diluted in lipid vehicle in large animals (ALMEIDA et at., 2004; MENDES et al., 2007; LINARDI et al., 2008) and the only report in small animals using this vehicle was made by FARIAS et al. (2005), who tested a dosage of $1.0 \mathrm{mg} / \mathrm{kg}$.

Due to inherent anatomic and physiologic properties such as elevated heart rates, purring, and variable positions of the heart in the thorax, echocardiographic evaluation in cats seems to be more reliable than traditional cardiovascular assessment such as auscultatory, electrocardiographic, radiographic, and clinical laboratory findings (PIPERS \& HAMLIN, 1980). It was described that $\% E F$ taken from M-mode echocardiogram may lead to errors, however the results are similar to the $\% \mathrm{SF}$, which is a trustworthy evidence of the cardiac performance (DUNKLE et al., 1986). There are few echocardiographic reports in cats after administration of $\mathrm{a}_{2}$-agonists (ALLEN \& DOWNEY, 1983; DUNKLE et al., 1986; LAMONT et al., 2002). Considering the myocardial depressor effect of the $\mathrm{a}_{2}-$ agonists, the evaluation of the left ventricular function after administration of these drugs is important due to their broad use in veterinary medicine (ALLEN \& DOWNEY, 1983).

The cardiac performance decreased after intravenous administration of xylazine or amitraz. Reduction in left ventricular function was previously reported in cats (DUNKLE et al., 1986), dogs (MUIR \& PIPER, 1977), horses (LINARDI et al., 2008), and calves (CAMPBELL et al., 1979) sedated with xylazine. Despite the decrease of $\% \mathrm{SF}, \% \mathrm{EF}$ and $\mathrm{IC}$ in cats sedated with amitraz, the reduction on cardiac performance was not as intense as in those sedated with xylazine. When a low $\% \mathrm{SF}$ is calculated, it may be secondary to poor preload, increased afterload or decreased contractility (BOON, 1998). However, an indication of poor preload or increased afterload is a decreased left ventricular diastolic chamber size (BOON, 1998), which did not occur in the present study. Central nervous system (CNS) depression in both treatments appeared to be severe enough to induce HR and ventricular dysfunction. Several studies have demonstrated that a decrease in $\mathrm{CO}$ values is not due to a direct negative action of the $\mathrm{a}_{2}$-agonist on myocardial contractility, but is secondary to the increased systemic vascular resistance and reduced HR (MUIR \& PIPER, 1977; AUTRAN DE MORAIS \& MUIR, 1995; LINARDI et al., 2008). A similar study in horses showed reduction in $\mathrm{CO}$ after xylazine or amitraz administration; however, as the \%SF and the $\%$ EF did not change significantly, the reduction in $\mathrm{CO}$ was probably due to a decrease in HR mediated by a reduction of sympathetic activity by $\mathrm{a}_{2}$-agonist action in the CNS (LINARDI et al., 2008).

It has been reported that $\mathrm{a}_{2}$-agonists can produce bradycardia and dysrhythmias, including sinoatrial block, $1^{\text {st }}$ and $2^{\text {nd }}$ AVB and sinus arrhythmia (PADDLEFORD \& HARVEY, 1999; CANOLA et al., 2007). These effects are most likely to occur secondary to the initial increase in blood pressure and reflex increase in vagal tone (LEMKE, 2004). First AVB in cats sedated with amitraz was first related by ANDRADE et al. (2006); however, the present study demonstrated that it may occur with different diluent preparations. Amitraz diluted in lipid solution causes AVB in horses (LINARDI et al., 2008) but not in dogs (FARIAS et al. 2005), and it has been associated with bradycardia in both of them. A delay in the electrical conduction system of the heart has been related with those dysfunctions (CANOLA et al., 2007).

The results compared in this study should be interpreted in view of two main limitations. First, we don't know if the amitraz dose was equipotent to the xylazine dose, then amitraz depression effects on cardiac contractility could had been underestimated. Secondly, the HR reduction in the group D at 20 minutes could indicate that the diluent used in this study may have potentiated the cardiac side effects caused by amitraz administration.

This study showed that either amitraz or xylazine induce reduction on left ventricular contractility and cardiac index associated with the bradycardia and $1^{\text {st }}$ AVB caused by the $\mathrm{a}_{2}$-adrenoreceptor interaction. 


\section{ACKNOWLEDGEMENT}

We thank the Conselho Nacional de Desenvolvimento Científico e Tecnológico (CNPq) for supporting this study.

\section{REFERENCES}

ALLEN, D. G.; DOWNEY, R. S. Echocardiographic assessment of cats anesthetized with xylazine-sodium pentobarbital. Canadian Journal of Comparative Medicine, v. 47, p. 281-283, 1983.

ALLEN, D. G.; DYSON, D. H.; PASCOE, P. J.; O'GRADY, M. R. Evaluation of a xylazine-ketamine hydrocloride combination in the cat. Canadian Journal of Veterinary Research, v. 50, p. 23-26, 1986.

ANDRADE, S. F.; SAKATE, M.; LAPOSY, C. B.; SANGIORGIO, F. Yohimbine and atipamezole on the treatment of experimentally induced amitraz intoxication in cats. International Journal of Applied Research in Veterinary Medicine, v. 4, p. 200-208, 2006.

ANDRADE, S. F.; SAKATE, M.; LAPOSY, C. B.; VALENTE, S. F.; BETTANIM, V. M.; RODRIGUES, L. T.; MARCICANO, J. Effects of amitraz intoxication in cats. Arquivo Brasileiro de Medicina Veterinária e Zootecnia, v. 59, p. 1.236-1.244, 2007.

AUTRAN DE MORAIS, H. S.; MUIR, W. W. The effects of medetomidine on cardiac contractility in autonomically blocked dogs. Veterinary Surgery, v. 24, p. 356-364, 1995.

BOON, J. A. (Ed.). Evaluation of size, function, and hemodynamics. In: Manual of veterinary echocardiography. $1^{\text {st }} \mathrm{ed}$. Pennsylvania: Williams \& Wilkins, 1998. p. 151-260.

CAMPBELL, K. B.; KLAVARO, P. A.; RICHARDSON, P.; ALEXANDER, J. E. Hemodynamic effects of xylazine in the calf. American Journal of Veterinary Research, v. 40, p. 1.777$1.780,1979$.

CANOLA, J. C.; VAlADÃO, C. A. A.; PORTUGAL, E. S.; CANOLA, P. A. Avaliação ecocardiográfica de eqüinos pré-medicados com N-butilbrometo de hioscina e sedados com romifidina. Ciência Animal Brasileira, v. 8, p. 833-839, 2007.

DUNKLE, N.; MOISE, S.; SCARLETT-KRANZ, J.; SHORT, C. E. Cardiac performance in cats after administration of xylazine or xylazine and glycopyrrolate: echocardiographic evaluations. American Journal of Veterinary Research, v. 47, p. 2.2122.216, 1986 .

FARIAS, A.; VALADÃO, C. A. A.; OLESKOVICZ, N.; DUQUE, J. C. Estudo eletrocardiográfico em cães submetidos à aplicação intravenosa de amitraz. Ars Veterinária, v. 21, p. 109-115, 2005.
GOLDEN, A. L.; BRIGTH, J. M.; DANIEL, G. B.; FEFEE, D.; SCHMIDT, D.; HARVEY, R. C. Cardiovascular effects of the $\mathrm{a}_{2}$-adrenergic receptor agonist medetomidine in clinically normal cats anesthetized with isoflurane. American Journal of Veterinary Research, v. 59, p. 509-513, 1998.

GROSS, M. E. Tranquilizantes, agonistas $\mathrm{a}_{2}$-adrenérgicos e agentes relacionados. In: ADAMS, H. R. (Ed.). Farmacologia e terapêutica em veterinária. 8. ed. Rio de Janeiro: Guanabara Koogan, 2003. p. 249-284.

HSU, H.; KAKUK, T. J. Effect oz amitraz and chlordimeform on heart hate and pupil diameter in rats: mediated by $\mathrm{a}_{2}$-adrenoreceptor. Toxicology and Applied Pharmacology, v. 73, p. 411-415, 1984.

LAMONT L, A.; BULMER, B. J.; SISSON, D. D.; GRIMM, K. A.; TRANQUILLI, W. J. Doppler echocardiographic effects of medetomidine on dynamic left ventricular outflow tract obstruction in cats. Journal of the American Veterinary Medical Association, v. 221, p. 1.276-1.281, 2002.

LEMKE, K. A. Perioperative use of selective alpha-2 agonists and antagonists in small animals. Canadian Veterinary Journal, v. 45, p. 475-480, 2004.

LINARDI, R. L.; CANOLA, J. C.; VALADÃO, C. A. A. Cardiovascular assessment in horses sedated with xylazine or amitraz. Arquivo Brasileiro de Medicina Veterinária e Zootecnia, v. 60, p. 329-334, 2008.

MENDES, M. C.; REIS, R. G.; VALADÃO, C. A. A.; MARQUES, J. A. Comparison of behavioral and clinical effects of intravenous amitraz or romifidine administration in horses. Arquivo Brasileiro de Medicina Veterinária e Zootecnia, v. 59, p. 1.433-1.438, 2007.

MUIR, W. W.; MASON, D. Cardiovascular system. In: THURMON, J. C.; TRANQUILLI, W. J.; BENSON, G. J. (Eds.). Lumb \& Jones' Veterinary Anesthesia. $3^{\text {rd }}$ ed. Philadelphia: Lea \& Feabiger, 1996. p. 62-114.

MUIR, W. W.; PIPER, F. S. Effect of xylazine on indices of myocardial contractility in the dog. American Journal of Veterinary Research, v. 38, p. 931-934, 1977.

PADDLEFORD, R. R.; HARVEY, R. C. Alpha ${ }_{2}$ agonists and antagonists. Veterinary Clinics Of North America: Small Animal Practice, v. 29, p. 737-745, 1999.

PIPERS, F. S.; HAMLIN, R. L. Clinical use of echocardiography in the domestic cat. Journal of American Veterinary Medical Association, v. 176, p. 57-61, 1980.

QUEIROZ-NETO, A.; CARREGARO, A. B.; ZAMUR, G.; HARKINS, J. D.; TOBIN, T.; MATAQUEIRO, M. I.; 
GONÇALVES, S. C. Effect of amitraz and xilazine on some physiological variables of horses. Arquivo Brasileiro de Medicina Veterinária e Zootecnia, v. 52, p. 27-32, 2000.

SINCLAIR, M. D. A review of the physiological effects of $a_{2-}$ -agonists related to the clinical use of medetomidine in small animal practice. Canadian Veterinary Journal, v. 44, p. 885-897, 2003.
VITAL, M. A. B. F. Introdução ao sistema nervoso autonomo. In: SPINOSA, H. S.; GÓRNIAK, S. L.; BERNARDI, M. M. Farmacologia aplicada à medicina veterinária. $3^{\text {rd }}$ ed. Rio de Janeiro: Guanabara Koogan, 2006. p. 51-66.

Protocolado em: 8 nov. 2009. Aceito em: 25 out. 2010. 